\title{
THE FIGHT AGAINST RELIGIOUS EXTREMISM (ON EXAMPLE OF IRAN)
}

\author{
(C) Tamara S. Olenich \\ Don state technical university. Rostov-on-Don, Russian Federation \\ tamara1970@inbox.ru
}

\begin{abstract}
Iran holds a specific geopolitical place in the world arena. The main focus of extremists is the Middle East region, the location of which draws the attention of all states of the world. Iran policy in the fight against terrorism in the region is an important factor of global security. This country reduces the costs of other states to fight terrorism, since Iran active concerns in the fight against terrorism undermines the expansionist potential of extremist organizations. The policy of deterring jihadists has a beneficial effect on constructive cooperation between Iran and other countries. The article examines the understanding of war and peace in Islam, according to the Qur'anic views. In Islamic principle there is no such category as "terrorism", but however Islam, being a world religion, opposes any kind of violence, unless it is caused by the need for selfdefense. The article focuses on the issues of fighting against religious extremism in the Islamic Republic of Iran and in the world. The article gives concepts of categories of jihad, considers the conditions for its legitimacy based on the norms of canon law. Special attention should be paid to the main directions of Iran domestic policy on countering terrorism.
\end{abstract}

Key words: jihad, religious extremism, information space, dialogue.

\section{[T.C. Оленич Борьба и предотвращение религиозного экстремизма (на примере Ирана)]}

Иран занимает особое геополитическое положение на мировой арене. Основным очагом экстремистов является Ближневосточный регион, расположение которого привлекает внимание всех государств мира. Политика Ирана в борьбе с терроризмом в регионе является важным фактором глобальной безопасности. Эта страна уменьшает расходы других государств на борьбу с терроризмом, так как активная вовлеченность Ирана в борьбу с терроризмом в регионе подрывает экспансионистский потенциал экстремистских организаций. Политика сдерживания джихадистов оказывает благотворное влияние на конструктивное сотрудничество между Ираном и другими странами. Рассматривается понимание войны и мира в исламе, согласно Кораническим представлениям. В исламском праве нет такой категории как "терроризм", однако ислам, как мировая религия, выступает против любого вида насилия, если оно не вызвано необходимостью самозащиты. Особое внимание уделяется вопросам борьбы с религиозным экстремизмом в ИРИ и в мире. Даются понятия категорий джихада, рассматриваются условия его правомерности на основе норм канонического права. Отдельное внимание заслуживают основные направления внутренней политики Ирана по противодействию терроризму.

Ключевые слова: джихад, религиозный экстремизм, информационное пространство, диалог.

Tamara S. Olenich - PhD of philosophy, professor. Don state technical university. Rostov-on-Don, Russian Federation.

Оленич Тамара Станиславовна - доктор фрилософских наук, профрессор. Донской государственный технический университет. Ростов-на-Дону, Россия.

One of the effective tools of anti-Iranian propaganda is the myth of the support of the Islamic Republic of international terrorism. An important aspect of the belief that Iran supports international terrorism is the seizure of the American Embassy at the dawn of the Islamic revolution. "Moral costs" in the history of American hostages in Iran has become a kind of indulgence to the participants of the anti-Iranian coalition. However, the fight against 
terrorism is one of the main priorities of the Islamic Republic of Iran. Therefore, this article is aimed at the analysis of domestic and foreign policy of the Islamic Republic of Iran in the context of fight against modern religious extremism.

It is important to note the active cooperation between Russia and Iran in this direction. The cooperation of Russia and Iran in the fight against terrorism is a good example for other countries, First Vice President of the Islamic Republic of Iran Eshak Jahangiri said at a meeting with Russian Prime Minister Dmitry Medvedev (RIA Novosti, November 30, 2017). The interaction between Moscow and Tehran effectively contributed to the fight against terrorism. This was stated on Wednesday by Iranian Foreign Minister Mohammad Javad Zarif at a meeting with Russian Foreign Minister Sergei Lavrov. "Cooperation between Iran and Russia could play a very effective role in the fight against terrorism and extremism in our sensitive region" Zarif stressed. According to him, the meetings of the presidents and the talks between the leaders of the diplomatic missions of Russia and Iran, cooperation on bilateral and regional issues "will bring peace and stability to our peoples and the region" (TASS, January 10, 2018).

Modern terrorism is not only international - it does not recognize state borders, and it can be financed from a variety of sources. Such organizations as "Jundallah" and "jeish al-ADL" are the clearest of examples. Terrorism in the province of Sistan and Baluchestan, evolving for decades, gives the opportunity to make some observations. First, it is obvious that it can be both secular and religious. Both forms, as history has shown, are equally dangerous, as for the sovereignty of the Islamic Republic, and for the lives of its individual citizens. Secondly, the fight against terrorism in Sistan and Baluchistan is impossible without cooperation with Pakistan and possibly Afghanistan. Ignoring the fact of cooperation cross the borderlines to fight the terrorism, by Islamabad, leads not only to international tensions, but also to these interstate conflicts and the expansion of the zone of chaos from Afghan territory to the South and West. In addition, Iran and Pakistan have already had examples of cooperation in the fight against terrorism in the past, as well as serious prospects for its renewal in the future [2].

Money is the lifeblood of any war and, at the same time, an excellent lubricant for political mechanisms. At a press conference on September 26, the U.S. Secretary of defense Chuck Hagel said that "for continuing operations [against IGIL] we need extra financing from Congress. And now we are working with the relevant committees, considering the question of how to obtain appropriations and financing, "the lobbyists of the US militaryindustrial complex realized that a holiday had come for them. According to American analysts, taking part in European and Arab allies and air war against the Caliphate, has already cost almost one billion dollars, and further costs will be even more - forecast U.S. Center for strategic and budgetary assessments from 2.4 to 3.8 billion dollars. Happiness swept through Wall Street, because, according to press reports, the shares of major military contractors, such as Raytheon, Lockheed Martin, Northrop Grumman and General Dynamics, has risen to a record high, surpassing quotes of 500 largest corporations of the index Standard \& Poor's. Actions of "anti-terrorist coalition"are the real feast for military contractors, corporations, and lobbyists. But Iran is obviously a stranger in this action. Is it compensated for the costs of fighting? No, because it is under the influence of sanctions. The only thing Washington can do in the case of Iran's participation is "to consider Iran's responsible position in the future [8].

On one of the first press conference, Iranian Ambassador to Moscow Mehdi Sanaei highlighted the main directions of foreign policy of Iran, and among them: "The elimination of uncertainties that is related to the peaceful nature of Iran's nuclear program, raising the country's place in the international arena, the elimination of "iranophobia" and "Islamophobia" in the world, the fight against religious extremism and the artificially created divisions among Muslims in the region, creating an atmosphere of trust in relations with the Arab 
countries of the Persian Gulf and constructive engagement with the West while standing firm and maintaining the policy of "unipolar world" [5].

The main principles of the Islamic Republic of Iran were: good relations with its neighbors, justice, respect for civil rights and freedoms. The Quran says: "If you argue with people of the Scripture, then give them the best reasons. And do not argue with one of them who is violent. Say: "We believed in what was revealed to us (i.e., in the Koran) and sent down to you (i.e., in the Torah and the Gospel). Our God and your God are one and the same [God is one], and we surrender to Him "(Quran, 29:46). The essence of this ayat is as follows: with the "people of the Scripture" do your best, except for those that behave outrageously.

A significant part of Islamic law is devoted to the situation of non-Muslim minorities in Islamic society. The basic rules of life of these minorities are reflected in the section of Ahl al-Zimma (Gentiles under the auspices of an Islamic state). According to these rules, the non-Muslim population in Islamic countries fulfilled certain obligations and was under full protection of the state. The payment of the jizya (taxing from Muslims in Muslim states), obeying the laws of the Islamic state, the obligation not to help the enemies, prevention of bans violations, hostile propaganda activities among Muslims, the desecration of religious relics were the main conditions by which non-Muslim minorities in the Muslim country were endowed with political and social rights. If these conditions were met, Muslims were obliged to treat them humanely and fairly. According to one of the hadiths, the Prophet said: "I will become the enemy of someone who oppresses the" protected "(ahya az-zimma) or puts them intolerable conditions" [6].

Islamic law pays a great attention to the concepts of war and peace. In Islam, war is referred to as Jihad. The word Jihad means "effort". In al-fiche this word is used in two meanings -general and special. In a General sense it means all the efforts and diligences on the path to God. In this sense, the efforts in the struggle for spiritual and moral perfection are characterized as the "great Jihad" (al-Jihad al-Akbar).

In Islamic law there are three categories of Jihad: the initial Jihad, defensive Jihad, and Jihad in the sense of liberation war. The initial Jihad begins, in order to establish Islam. The Quran says about this: "it is Prescribed to fight [with the Meccan polytheists], but you hated it. But it also happens that you hated it, which is good for you, and what you desire, it is evil for you. God knows [about it], and you do not know" (Qur'an, 2:216) [6].

Initial Jihad occurs under presence of the Prophet or "infallible" imams - without the presence of the Prophet or "infallible" imams' maintenance or initial announcement of Jihad is not valid. In addition, the conduct of military actions (according to the initial jihad) during the four sacred months (rajab, dhu-I-ka'da, dhu-I-hijjah and muharram) is prohibited. But "[Fight] in the prohibited month, [if they acted] in this month " (Quran, 2: 194). It is important to note that defensive war in Islam means the military actions of the Islamic state, aimed at protecting the country from invaders. This rule is now recognized by international law as allowed defense.

Islamic radicalism arises in the most aggressive form in the second half of the 20th century as a desire to return to the "primordial" early Islam, in which everything was just, and also to reject all Western, alluvial. Consequently, such radicalism is basically a product of interaction between East and West. Historically, Islam for many centuries harmoniously had been adopting a Greek wisdom, and Persian culture, and various patterns of local customs. What offers Iran, on the basis of the Qur'anic concepts of war and peace, to the fight against religious terrorism? This question was answered by Mehdi Sanaei in his article "Globalization and dialogue between religions" - "At a time when some advocates of modernization see religion as the cause of all the conflicts and terrorists in his anger at the lack of control of globalization, violent, religious leaders on the basis of tolerance among reli- 
gions, and peace aspirations religions could assist in the establishment of mutual understanding and peace on earth. Thus, the modern world requires a dialogue between religions. Such a dialogue, on the one hand, helps to clarify the relationship between religions, globalization and the preservation of religious values. On the other hand, he reminds us of the role of religion in peace and defusing tensions in the world" [3]. This aspect was implemented at the meeting of the Ambassador of Iran to the President of the Council of Muftis of Russia mufti Sheikh Ravil Gainutdin, during which the parties noted the high level of relations between Muslims of Russia and Iran. In turn, Mr. Mehdi Sanaei also noted the positive role of Muslims in strengthening the authority of Russia in the international arena, stressing that moderate and progressive Islam, which differ Muslims of Russia, is one of the determining factors contributing to the fight against terrorism and radicalism.

Iran sees the UN as a most important partner in the fight against religious terrorism. The UN should play a more active role in the fight against terrorism. This was stated by the President of Iran Hasan Rouhani during the international conference "World against violence and extremism (December 2014) in Tehran - "The World without violence can only be created through cooperation of governments who should conduct a single policy, - he stressed [7]. The President also called for enhancing regional and international cooperation to fight against terrorist organizations in Syria and Iraq.

"One of the forms of antiterrorism protection is the fight against the sources of its financial provision. In 2006, Iran passed a law banning money laundering, which emphasizes that money-laundering is an important part of the financing of terrorism. The law puts in strict control and a limiting of money resources to prevent terrorists from using this source of income. He calls for cooperation with international institutions dealing with countering the financing of terrorism. In this direction, Iran actively cooperates with the group for the development of financial measures to prevent money laundering, which is engaged in the development of world standards in the field of countering money laundering and the financing of terrorism. After the adoption of the above-mentioned law, another important step in the implementation of its provisions was the adoption of a new law on banning the financing of terrorism in 2015. In fact, these two documents reflect two UN documents: the International Convention for the Suppression of the Financing of Terrorism of 1999 and The UN Security Council Resolution 1373 on Fighting against International Terrorism of September 28, 2001" [1].

To communicate with like-minded people now, it is enough to have a personal computer and Internet access. So, virtualized extremist manifestations freely and uncontrollably penetrate into every house. In this regard, the role of information factor and mass communications in the spread of extremism among youth is increasing. Immature and distorted consciousness finds a culture media in the information flows, spontaneously or purposefully generated in an uncontrolled global networks are increasingly used to spread extremist views. It causes the growth and changing of forms of youth extremism [4]. In this regard, the new structure of law enforcement agencies - cyberpolice is designed to track the creation of the youth terrorist organizations. The revolutionary guards (IRGC) in a short time has created mechanisms to counter the penetration into the information space of the country of such organizations. Already in July 2009, Iran adopted the Law "On the Control of Cyberspace", according to which it was possible to monitor, with the help of Internet providers, the actions of users on the Internet without the sanction of the court. In addition, for the dissemination of illegal information in the network the criminal liability was also introduced. IRGC at the same time controls a large block of stock in state-owned telecommunications company $\mathrm{DCl}$ - Data Communications Iran - which is also the largest Iranian provider. Thus, Iran has seriously approached the problem of its own information security - Iran is developing its own software to create a national search system. 


\section{Лumepamypa}

1. Джаббари Насир $X$. Потенциал Ирана в борьбе с международным терроризмом // Вестник Российского университета дружбы народов. Серия: Международные отношения. 2016. Т. 16. № 4.

2. Главный источник ирано-пакистанской напряженности // http://www.iran.ru/news/analytics/92691/Glavnyy_istochnik_irano_pakistanskoy_n apryazhennosti.

3. Глобализация и диалог между религиями // http://www.abna.ir/russian/cultural/islamicunity/archive/2014/05/17/605494/story.html

4. Кубякин Е.О. Молодежный экстремизм в эпоху глобализации информационнокоммуникационной среды общественной жизни. Краснодар,2012.

5. Мехди Санаи. Новый Посол Ирана в Москве /I http://russian.irib.ir/analitika/reportazh/item/194324.

6. Мехди Санаи. Мусульманское право и политика. М., 2013.

7. Мир против насилия и экстремизма // http://islam.kz/ru/news/v-mire/mir-protivnasiliya-i-ekstremizma-mejdunarodnaya-konferentsiya-v-irane-396/.

8. Станет ли Иран участником антитеррористической коалиции?// http://www.iran.ru/news/analytics/94839/Stanet_li_Iran_uchastnikom_antiterroristic heskoy_koalicii.

\section{References}

1. Jabbari Nasir H. Iran's Potential in Combating International Terrorism // Bulletin of the Russian Peoples Friendship University. Series: International relations. 2016. Vol. 16. № 4.

2. The main source of Iranian-Pakistani tension // http://www.iran.ru/news/analytics/92691/Glavnyy_istochnik_irano_pakistanskoy_napryazhennosti.

3. Globalization and dialogue between religions // http://www.abna.ir/russian/cultural/islamic-unity/archive/2014/05/17/605494/story.html

4. Kubyakin E.O. Youth extremism in the era of globalization of the information and communication environment of public life. Krasnodar, 2012.

5. Mehdi Sanai. The new Iranian Ambassador in Moscow // http://russian.irib.ir/analitika/reportazh/item/194324.

6. Mehdi Sanai. Muslim law and politics. M., 2013.

7. The World Against Violence and Extremism // http://islam.kz/en/news/v-mire/mirprotiv-nasiliya-i-ekstremizma-mejdunarodnaya-konferentsiya-v-irane-396/.

8. Will Iran become a participant in the antiterrorist coalition? // http://www.iran.ru/news/analytics/94839/Stanet_li_Iran_uchastnikom_antiterroristicheskoy_koalicii. 